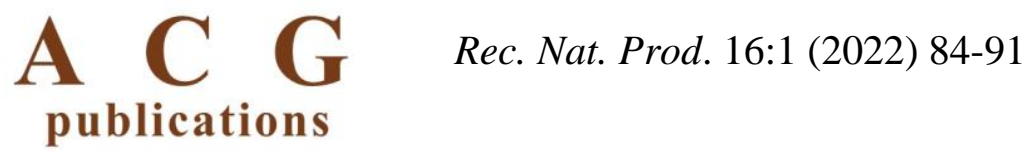

\title{
A New 2,3-Dioxygenated Flavanone and Other Constituents from Dysosma difformis
}

\section{Bui Van Thanh $\oplus^{1}$, Nguyen Thi Van Anh $\oplus^{1}$, Chu Thi Thu Ha $\oplus^{1}$, Do Hoang Giang $\oplus^{2}$, Truong Thi Lien $\oplus^{2}$, Ninh Khac Thanh Tung $\oplus^{2}$, and Nguyen Tien Dat ${ }^{2 \cdot}$}

${ }^{1}$ Institute of Ecology and Biological Resources, Vietnam Academy of Science and Technology, 18Hoang Quoc Viet, Cau Giay, Hanoi, Vietnam

${ }^{2}$ Center for Research and Technology Transfer, Vietnam Academy of Science and Technology, 18Hoang Quoc Viet, Cau Giay, Hanoi, Vietnam

(Received March 16, 2021; Revised May 19, 2021; Accepted May 26, 2021)

\begin{abstract}
A novel 2,3-dioxygenated flavanone, dysosmaflavanone (2), along with five known phenolic compounds including podophyllotoxin (1), podoverin A (3), kaempferol (4), 8,2'-diprenyl quercetin 3-methyl ether (5), and ethyl $\beta$-D-glucoside (6) were isolated from the roots of the plant Dysosma difformis. Their structures were elucidated via spectroscopic analysis. Besides podophyllotoxin and kaempferol, the rest of the compounds were isolated from the genus Dysosma for the first time. Dysosmaflavanone, which possesses a rare 2,3-dioxygenated skeleton, could be regarded as an important chemotaxonomic marker. The antioxidant and antidiabetic activities of the isolated compounds were evaluated.
\end{abstract}

Keywords: Dysosma difformis; Berberidaceae; 2,3-dioxygenated flavanone; dysosmaflavanone. @ 2021 ACG Publications. All rights reserved.

\section{Introduction}

Dysosma difformis (Hemsl. \& E.H.Wilson) T.H.Wang (syn: Podophyllum tonkinense Gagnep) (Berberidaceae) is widely used as a traditional medicine to treat sore throats, pimples, and snakebites [1]. Aglycone, aryltetralin lignan glycosides, and flavonols [2-5], which exhibit antiproliferative [6], anticancer [7], and angiogenesis-inhibiting [8] activities, are produced by species of the Dysosma genus. Podophyllotoxin (1), the major aryltetralin lignan in Dysosma plants, exhibits anticancer properties [9]. However, few investigations into the phytochemical constituents of $D$. difformis have been conducted $[10,11]$. In the present study, we describe the isolation and structure of a new 2,3dioxygenated flavanone (2) and five other known compounds isolated from the roots of $D$. difformis (Figure 1).

·Corresponding author: E-Mail: ngtiend@imbc.vast.vn; Phone: 84-24-37568422

The article was published by ACG Publications

http://www.acgpubs.org/journal/records-of-natural-products January-February 2022 EISSN:1307-6167

DOI: http://doi.org/10.25135/rnp.256.21.03.2017

Available online June 03, 2021 
<smiles>COc1cc([C@H]2c3cc4c(cc3[C@@H](O)[C@@H]3COC(=O)[C@H]23)OCO4)cc(OC)c1OC</smiles>

1<smiles>O=c1c(O)c(-c2ccc(O)cc2)oc2cc(O)cc(O)c12</smiles>

4<smiles></smiles>

2<smiles>COc1c(-c2ccc(O)c(O)c2CC=C(C)C)oc2c(CC=C(C)C)c(O)cc(O)c2c1=O</smiles>

5<smiles>COc1c(-c2ccc(O)c(O)c2CC=C(C)C)oc2cc(O)cc(O)c2c1=O</smiles>

3<smiles>CCOC(O)C1C(O)C(O)C(O)C1O</smiles>

6

Figure 1. Structures of the isolated compounds 1-6

\section{Materials and Methods}

\subsection{Plant Material}

The underground parts of Dysosma difformis were collected from Ha Giang province, Vietnam, in December 2018. The sample was identified by one of the authors (Bui Van Thanh) and a voucher specimen (No. Berb_HG_10) was deposited at the herbarium of the Institute of Ecology and Biological Resources.

\subsection{General Procedures}

NMR experiments were performed on a Bruker AM500 FT-NMR spectrometer with tetramethylsilane (TMS) as an internal standard. Optical rotations were read on a JASCO P-2000 digital polarimeter. High-resolution mass spectra (ESI positive mode) were obtained with a Thermo LTQ Orbitrap XL mass spectrometer. Thin-layer chromatography (TLC) was performed on precoated silica gel $60 \mathrm{~F}_{254}$ plates (Merck, Germany), and spots were detected under UV illumination $254 \mathrm{~nm}$ and spraying with $\mathrm{H}_{2} \mathrm{SO}_{4} 10 \%$ reagents followed by heating. Column chromatography (CC) was carried out using D101 resin (0.3-1.5 mm, Extrepure, China), silica gel 60 (70-230 mesh, Merck, Germany), or YMC RP-C18 resin $(150 \mu \mathrm{m}, \mathrm{YMC}$, Japan). Preparative HPLC was conducted on a Thermo Dionex Ultimate 3000 system, using a YMC-Pack ODS-A $(5 \mu \mathrm{m}, 250$ x $20 \mathrm{~mm}$ i.d., YMC Co., Ltd., Kyoto, Japan) column, with a $5 \mathrm{~mL} / \mathrm{min}$ flow rate.

\subsection{Extraction and Isolation}

The air-dried powdered materials $(1.3 \mathrm{~kg})$ were extracted with ethanol $(\mathrm{EtOH})(2 \mathrm{~L} \times 4$ times $)$ in an ultrasonic bath for $30 \mathrm{~min}$. The combined extracts were concentrated to obtain an ethanol crude residue $(160.5 \mathrm{~g})$, which was then loaded on a column $(300 \times 100 \mathrm{~mm}$ i.d. $)$ filled with $1 \mathrm{~kg}$ of D101 resin. After the sample was completely adsorbed, the column was eluted by $10 \mathrm{~L}$ of deionized water, 


\section{New 2,3-dioxygenated flavanone from Dysosma difformis}

following by increasing concentrations of $\mathrm{MeOH}(25 \%, 50 \%$, and $100 \%)$ in water, to obtain four fractions, F1-F4. Fraction F3 was subjected to a silica gel CC with gradient mixtures of n-hexaneacetone (10/1-1/1, v/v) to afford eleven subfractions (F3.1 - F3.11). Fraction F3.7 was separated using silica gel eluted with $\mathrm{CH}_{2} \mathrm{Cl}_{2}-\mathrm{MeOH}(70 / 1, \mathrm{v} / \mathrm{v})$ to yield podophyllotoxin (1) (416.6 mg) and ten subfractions (F3.7.2-F3.7.11). Fraction F3.7.6 was purified by preparative HPLC (60 min, 40-75\% $\mathrm{MeOH}$ in $\left.\mathrm{H}_{2} \mathrm{O}\right)$ to afford the new flavanonol, dysosmaflavanone (2) $(9.1 \mathrm{mg})$, and podoverin $\mathrm{A}(3)$ $(40.1 \mathrm{mg})$. Kaempferol (4) $(53.9 \mathrm{mg})$ was purified by recrystallizing the fraction F3.7.11 in $\mathrm{MeOH}-$ $\mathrm{H}_{2} \mathrm{O}(1 / 1, \mathrm{v} / \mathrm{v})$. Fraction F3.6 was isolated using a silica gel column eluted with $\mathrm{CH}_{2} \mathrm{Cl}_{2}-\mathrm{MeOH}(60 / 1$, $\mathrm{v} / \mathrm{v})$, following by a YMC RP-C18 column eluted with $\mathrm{MeOH}-$ water (3:1, v/v) to yield 8,2'-diprenyl quercetin 3-methyl ether (5) $(7.5 \mathrm{mg})$. Fraction F2 was chromatographed on a silica gel column and eluted with $\mathrm{CH}_{2} \mathrm{Cl}_{2}-\mathrm{MeOH}-\mathrm{H}_{2} \mathrm{O}(5 / 1 / 0.1, \mathrm{v} / \mathrm{v} / \mathrm{v})$ to yield ethyl $\beta$-D-glucoside (6) $(75.3 \mathrm{mg})$. The purity of all isolated compounds was $>97 \%$ via HPLC (data not shown).

Dysosmaflavanone (2): Pale yellow powder; $[\alpha]_{\mathrm{D}}{ }^{25}+0.15(c 0.2, \mathrm{MeOH})$; HRMS (ESI positive) $\mathrm{m} / \mathrm{z}$ $389.1218\left([\mathrm{M}+\mathrm{H}]^{+}\right.$, calcd for $\left.\mathrm{C}_{20} \mathrm{H}_{21} \mathrm{O}_{8}, 389.1236\right), 411.1070\left([\mathrm{M}+\mathrm{H}]^{+}\right.$, calcd for $\mathrm{C}_{20} \mathrm{H}_{20} \mathrm{O}_{8} \mathrm{Na}$, 411.1056), $799.2259\left([2 \mathrm{M}+\mathrm{Na}]^{+}\right), 373.0957\left(\left[\mathrm{M}-\mathrm{CH}_{3}\right]^{+}\right), 343.0864\left(\left[\mathrm{M}-\mathrm{OC}_{2} \mathrm{H}_{5}\right]^{+}\right)$. NMR data of the compound in $\mathrm{CD}_{3} \mathrm{OD}$ and DMSO- $d_{6}$ were shown in Table 1.

\subsection{DPPH Radical Scavenging Assay}

2,2-Diphenyl-1-picrylhydrazyl (DPPH) radical-scavenging activity was conducted by modified a previous method [12]. Briefly, $10 \mu \mathrm{L}$ of each sample was mixed with $190 \mu \mathrm{L}$ of DPPH (Sigma-Aldrich) in methanol before incubated at $37^{\circ} \mathrm{C}$ for 20 minutes. The absorbance was measured at $517 \mathrm{~nm}$. Ascorbic acid was used as a positive control.

\subsection{Superoxide Radical Scavenging Assay}

Superoxide radical scavenging activity was measured by a reported method with some modification [13]. In brief, $100 \mu \mathrm{L}$ of the sample dissolved in DMSO was mixed with $300 \mu \mathrm{L}$ of the

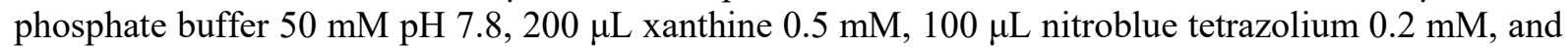
$100 \mu \mathrm{L}$ of xanthine oxidase. The mixture was incubated at $37^{\circ} \mathrm{C}$ for 60 minutes then measured at the wavelength of $550 \mathrm{~nm} .(+)$-catechin was used as a positive control.

\subsection{Hydroxyl Radical Scavenging Assay}

Hydroxyl radical inhibition was evaluated by a modified method of the previously reported assay [13]. The mixture containing $50 \mu \mathrm{L}$ of the test sample, $100 \mu \mathrm{L}$ of the phosphate buffer $50 \mathrm{mM}$ $\mathrm{pH} 7.8,100 \mu \mathrm{L}$ of deoxyribose $2.8 \mathrm{mM}$, and $100 \mu \mathrm{L}$ of $\mathrm{Fe}\left(\mathrm{NH}_{4}\right)_{2}\left(\mathrm{SO}_{4}\right)_{2} 500 \mu \mathrm{M}$ was incubated for $1 \mathrm{~h}$ at $37{ }^{\circ} \mathrm{C}$. After adding $250 \mu \mathrm{L}$ of trichloroacetic acid $(10 \%, \mathrm{w} / \mathrm{v})$ and $250 \mu \mathrm{L}$ of thiobarbituric acid $(1 \%, w / v)$, the reaction mixture was boiled for $15 \mathrm{~min}$ in a water bath. The color development was measured at $532 \mathrm{~nm}$. (+)-catechin was used as a positive control.

\section{7. $\alpha$-Glucosidase Inhibition Assay}

The $\alpha$-glucosidase enzyme inhibition activity was assessed by modifying a previous method [14]. $50 \mu \mathrm{L}$ of the sample solution in methanol was mixed with $100 \mu \mathrm{L}$ of $\alpha$-glucosidase (G0660750UN, Sigma-Aldrich) $0.5 \mathrm{U} / \mathrm{mL}$ and $100 \mu \mathrm{L}$ of phosphate buffer $100 \mathrm{mM}$ (pH 6.8-7.0). After 10 min of pre-incubation at room temperature, $50 \mu \mathrm{L}$ of $5 \mathrm{mM}$-nitrophenyl- $\alpha$-D-glucopyranoside solution was added, and the solution was incubated at $37^{\circ} \mathrm{C}$ for $30 \mathrm{~min}$. The absorbance of released 4nitrophenol was measured at $405 \mathrm{~nm}$ by using a microplate reader. Acarbose was used as a positive control.

\section{8. $\alpha$-Amylase Inhibition Assay}


The $\alpha$-amylase enzyme inhibitory activity was evaluated by the previously reported method [14] with some modifications. The substrate was prepared by boiling $80 \mathrm{mg}$ of potato starch in $4 \mathrm{~mL}$ phosphate buffer ( $\mathrm{pH}$ 7.0) for $5 \mathrm{~min}$, then it was left at room temperature to cool down. Next, $100 \mu \mathrm{L}$ of the sample solution was mixed with $50 \mu \mathrm{L}$ of the substrate and $30 \mathrm{~mL}$ of $100 \mathrm{mM}$ phosphate buffer (pH 7.0). After $5 \mathrm{~min}$ of pre-incubation, $50 \mu \mathrm{g} / \mathrm{mL} \alpha$-amylase (A8220, Sigma-Aldrich) solution was added, and the solution was incubated at $37^{\circ} \mathrm{C}$ for $15 \mathrm{~min}$. The reaction was stopped by adding $50 \mu \mathrm{L}$ of glacial acetic acid, then $50 \mathrm{~mL}$ iodine solution was added. The absorbances were measured at 650 nm by using a microplate reader. Acarbose was used as a positive control.

\section{Results and Discussion}

\subsection{Structure Elucidation}

Compound 2 was obtained as a pale-yellow powder, which generated $[\mathrm{M}+\mathrm{H}]^{+}$and $[\mathrm{M}+\mathrm{Na}]^{+}$ ions with mass-to-charge ratio $(\mathrm{m} / \mathrm{z})$ values of 389.1218 and 411.1070 , respectively, when analysed by high resolution electrospray ionization mass spectrometry; this suggested that the compound had a molecular formula of $\mathrm{C}_{20} \mathrm{H}_{20} \mathrm{O}_{8}$. Fragment ions with $\mathrm{m} / \mathrm{z} 373.0957\left[\mathrm{M}^{-} \mathrm{CH}_{3}\right]^{+}$and 343.0864 [M$\left.\mathrm{OC}_{2} \mathrm{H}_{5}\right]^{+}$revealed the presence of an ethoxy group in the compound 2 structure. ${ }^{1} \mathrm{H}$ NMR analysis of compound 2 also indicated an ethoxy group [3.37 $(1 \mathrm{H}$, dq overlap, $\mathrm{H}-1 \mathrm{a} "), 3.52(1 \mathrm{H}, \mathrm{dq}, J=7.5,2.5$ $\mathrm{Hz}, \mathrm{H}-1 \mathrm{~b} "), 1.04(3 \mathrm{H}, \mathrm{t}, J=7.5 \mathrm{~Hz}, \mathrm{H}-2 ")]$ and protons in an acetonyl system [2.25 $(1 \mathrm{H}, \mathrm{d}, J=15.5$ $\mathrm{Hz}, \mathrm{H}-1 \mathrm{a} " '), 3.08$ (1H, d, $\left.J=15.5 \mathrm{~Hz}, \mathrm{H}-1 \mathrm{~b}^{\prime \prime}\right), 2.28$ (3H, s, H-3"')]. In addition, two meta-coupled doublets [5.99 $(1 \mathrm{H}, \mathrm{d}, J=2.5 \mathrm{~Hz}, \mathrm{H}-6), 6.01(1 \mathrm{H}, \mathrm{d}, J=2.5 \mathrm{~Hz}, \mathrm{H}-8)]$ and an $\mathrm{A}_{2} \mathrm{~B}_{2}$-system $[7.43(2 \mathrm{H}$, $\left.\left.\mathrm{d}, J=8.5 \mathrm{~Hz}, \mathrm{H}-2^{\prime}, 6^{\prime}\right), 6.84\left(2 \mathrm{H}, \mathrm{d}, J=8.5 \mathrm{~Hz}, \mathrm{H}-3^{\prime}, 5^{\prime}\right)\right]$ were detected, indicative of a flavonoid skeleton with a symmetrical B-ring.

Table 1. ${ }^{1} \mathrm{H}(500 \mathrm{MHz})$ and ${ }^{13} \mathrm{C}(125 \mathrm{MHz})$ NMR data for compound 2

\begin{tabular}{|c|c|c|c|c|}
\hline \multirow{2}{*}{ Position } & \multicolumn{2}{|r|}{ in $\mathrm{CD}_{3} \mathrm{OD}$} & \multicolumn{2}{|r|}{ in DMSO- $d_{6}$} \\
\hline & $\delta_{\mathbf{C}}$ & $\delta_{H}$ & $\delta_{\mathrm{C}}$ & $\delta_{H}$ \\
\hline 2 & 108.9 & & 107.5 & \\
\hline 3 & 79.8 & & 77.1 & \\
\hline 4 & 196.5 & & 194.6 & \\
\hline $4 a$ & 100.8 & & 99.2 & \\
\hline 5 & 165.5 & & 163.4 & \\
\hline 6 & 97.5 & $5.99(1 \mathrm{H}, \mathrm{d}, J=2.5 \mathrm{~Hz})$ & 96.5 & $5.97(1 \mathrm{H}, \mathrm{brs})$ \\
\hline 7 & 168.3 & & 166.8 & \\
\hline 8 & 96.7 & $6.01(1 \mathrm{H}, \mathrm{d}, J=2.5 \mathrm{~Hz})$ & 95.6 & $5.97(1 \mathrm{H}, \mathrm{brs})$ \\
\hline $8 \mathrm{a}$ & 160.1 & & 158.4 & \\
\hline $1^{\prime}$ & 126.6 & & 124.4 & \\
\hline $2^{\prime} ; 6^{\prime}$ & 131.0 & $7.43(2 \mathrm{H}, \mathrm{d}, J=8.5 \mathrm{~Hz})$ & 129.7 & $7.32(2 \mathrm{H}, \mathrm{d}, J=8.5 \mathrm{~Hz})$ \\
\hline $3^{\prime}, 5^{\prime}$ & 115.5 & $6.84(2 \mathrm{H}, \mathrm{d}, J=8.5 \mathrm{~Hz})$ & 114.5 & $6.82(2 \mathrm{H}, \mathrm{d}, J=8.5 \mathrm{~Hz})$ \\
\hline $4^{\prime}$ & 159.5 & & 158.1 & \\
\hline $1 "$ & 60.3 & $3.37(1 \mathrm{H}, \mathrm{dq}$, overlap $)$ & 58.9 & $3.42(1 \mathrm{H}, \mathrm{dq}$, overlap) \\
\hline & & $3.52(1 \mathrm{H}, \mathrm{dq}, J=7.5,2.5 \mathrm{~Hz})$ & 50. & $3.25(1 \mathrm{H}, \mathrm{dq}, J=7.5,2.5 \mathrm{~Hz})$ \\
\hline $2 "$ & 15.1 & $1.04(3 \mathrm{H}, \mathrm{t}, J=7.5 \mathrm{~Hz})$ & 14.7 & $0.94(3 \mathrm{H}, \mathrm{t}, J=7.5 \mathrm{~Hz})$ \\
\hline $1 " '$ & 41.7 & $2.25(1 \mathrm{H}, \mathrm{d}, J=15.5 \mathrm{~Hz})$ & 42.5 & $2.28(1 \mathrm{H}, \mathrm{d}, J=15.5 \mathrm{~Hz})$ \\
\hline & & $3.08(1 \mathrm{H}, \mathrm{d}, J=15.5 \mathrm{~Hz})$ & & $2.81(1 \mathrm{H}, \mathrm{d}, J=15.5 \mathrm{~Hz})$ \\
\hline 2"' & 213.9 & & 209.0 & \\
\hline 3"' & 31.8 & $2.28(3 \mathrm{H}, \mathrm{s})$ & 31.2 & $2.10(3 \mathrm{H}, \mathrm{s})$ \\
\hline $3-\mathrm{OH}$ & & & & $6.33(1 \mathrm{H}, \mathrm{brs})$ \\
\hline $5-\mathrm{OH}$ & & & & $11.28(1 \mathrm{H}, \mathrm{brs})$ \\
\hline 7-OH & & & & $10.90(1 \mathrm{H}, \mathrm{brs})$ \\
\hline 4'-OH & & & & $9.66(1 \mathrm{H}, \mathrm{s})$ \\
\hline
\end{tabular}

Twenty carbons were detected via ${ }^{13} \mathrm{C}$ NMR, including ten quaternary carbons, six methines, two methylenes, and two methyl groups, which were confirmed via heteronuclear single quantum 


\section{New 2,3-dioxygenated flavanone from Dysosma difformis}

coherence. Carbon chemical shifts indicated two carbonyl groups $\left(\delta_{C} 196.5\right.$ and 213.9), four oxygenated aromatic carbons $\left(\delta_{C} 165.5,168.3,160.1\right.$, and 159.5$)$, a doubly oxygenated $\mathrm{sp}^{3}\left(\delta_{C} 108.9\right)$, an oxygenated aliphatic carbon $\left(\delta_{C} 79.8\right)$, and two other aromatic carbons $\left(\delta_{C} 126.6\right.$ and 100.8). Erigeroflavanone [15] is a 2,3-dioxygenated flavanone containing an ethoxy group, an acetoxy group, and four hydroxyl groups. Heteronuclear multiple bond correlations (HMBCs) (Figure 2) between $\mathrm{H}_{2}-$ $1 "\left(\delta_{H} 3.37,3.52\right)$ and $\mathrm{C}-2\left(\delta_{C} 108.9\right)$ revealed that the ethoxy group was located at position C-2. Furthermore, HMBCs between $\mathrm{H}_{2}-1{ }^{\prime \prime}\left(\delta_{H} 3.08,2.25\right)$ and C-2 $\left(\delta_{C} 108.9\right), \mathrm{C}-3\left(\delta_{C} 79.8\right)$, and C-4 $\left(\delta_{C}\right.$ 196.5) revealed an acetonyl group located at C-3. The molecular profile of compound 2 was similar to that of the flavanone cepaflava B [16]; however, cepaflava B contains a methoxy group at C-3 and an ABX system (Table S1).

The near-zero optical rotation and lack of significant Cotton effect on the compound 2 circular dichroism spectrum (data not shown) suggested that the mixture was racemic. To observe the -OH groups of compound $\mathbf{2}$ in more detail, one-dimensional and two-dimensional NMR experiments were conducted using deuterated dimethyl sulfoxide. Nuclear Overhauser effect spectroscopy revealed correlations between the 3-OH proton and $\mathrm{H}-1$ ", and between $\mathrm{H}-1{ }^{\prime \prime}$ and $\mathrm{H}-3$ ', while there was no correlation between H-1" and H-1"' (Figures 2 and S12); this suggested an erythro-orientation between the ethoxy group at C-2 and the hydroxyl group at C-3 of compound $\mathbf{2}$. Thus, we determined compound $\mathbf{2}$ to be (2RS,3SR)-2-ethoxy-3,5,7-trihydroxy-2-(4-hydroxyphenyl)-3-(2-oxopropyl)chroman-4-one and named the compound "dysosmaflavanone".

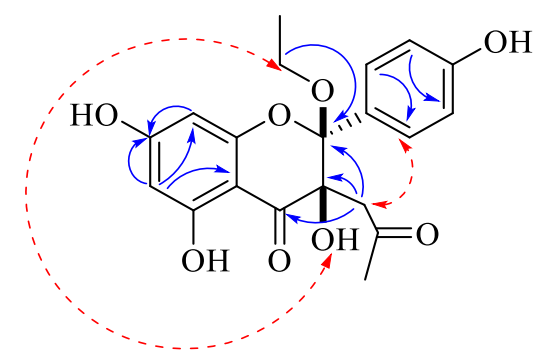

Figure 2. Key HMBC $(\longrightarrow)$ and NOESY $(+\cdots \cdots \cdots)$ correlations of the compound 2

Next, we performed high-performance liquid chromatography (HPLC) to further examine compound 2. Extractions were performed on the roots of $D$. difformis with methanol and acetone, then analysed with an HPLC-diode array detector system. Compound $\mathbf{2}$ was not detected in the methanol or acetone extracts (data not shown), suggesting that the compound was an artefact of the ethanol extraction process. Recently, similar 2,3-dioxygenated flavanones were discovered to be artificial products generated during flavonoid extraction from plant materials [16]. Furthermore, flavonoids that are oxygenated at both the C-2 and C-3 positions are rarely found in nature [15, 17]; thus, the origin of compound 2 must be investigated further.

The other five isolated phenolic compounds, podophyllotoxin (1) [18], podoverine A (3) [19], kaempferol (4) [20], 8,2'-diprenyl quercetin 3-methyl ether (5) [21], and ethyl $\beta$-D-glucoside (6) [22], were identified by comparing our NMR data to previous reports. Podophyllotoxin (1) is an effective anticancer agent [23] and 8,2'-diprenyl quercetin 3-methyl ether (5) is significantly more cytotoxic against human mammary adenocarcinoma and breast cancer cell lines compared to taxol [21].

\subsection{Biological Activities}

In this study, the isolated compounds were evaluated for their antioxidant capacity via scavenging 2,2-diphenyl-1-picrylhydrazyl (DPPH), hydroxyl, and superoxide radicals. Their antidiabetic activity was also tested on digestive enzymes $\alpha$-glucosidase and $\alpha$-amylase. As shown in Table 2, the five phenolic compounds exhibited higher DPPH scavenging activity than ascorbic acid, while showing weaker hydroxyl radical and superoxide radical inhibition compared to catechin. The inhibitory activities of all isolated compounds against $\alpha$-glucosidase and $\alpha$-amylase were evaluated in comparison with acarbose, an antidiabetic agent. Dysosmaflavanone inhibited $\alpha$-glucosidase and $\alpha$ - 
amylase activities at lower doses than acarbose. Among the six compounds, kaempferol showed the highest antioxidant and while 8,2'-diprenyl quercetin 3-methyl ether exhibited strongest inhibition against digestive enzymes, while ethyl $\beta$-D-glucoside did not exhibit any antioxidant or antidiabetic activity. The new dysosmaflavanone showed similar effects with kaempferol in inhibiting $\alpha$ glucosidase and $\alpha$-amylase.

Table 2. Inhibitory effects* of the isolated compounds against free radicals and digestive enzymes

\begin{tabular}{cccccc}
\hline Compounds & DPPH & $\mathbf{O H}^{\bullet}$ & $\mathbf{O}_{2}^{-\bullet}$ & $\boldsymbol{\alpha}$-glucosidase & $\boldsymbol{\alpha}$-amylase \\
\hline Podophyllotoxin (1) & $28.6 \pm 1.1$ & $61.2 \pm 3.0$ & $77.2 \pm 6.2$ & $1500 \pm 131$ & $1703 \pm 99$ \\
Dysosmaflavanone (2) & $35.2 \pm 2.9$ & $20.3 \pm 1.7$ & $69.7 \pm 5.0$ & $1382 \pm 120$ & $1330 \pm 111$ \\
Podoverine A (3) & $42.3 \pm 2.4$ & $22.8 \pm 1.8$ & $65.4 \pm 3.7$ & $1962 \pm 169$ & $1297 \pm 109$ \\
Kaempferol (4) & $17.7 \pm 0.9$ & $12.9 \pm 0.9$ & $42.3 \pm 1.1$ & $1360 \pm 105$ & $1246 \pm 117$ \\
8,2'-Diprenyl Quercetin & $44.4 \pm 3.0$ & $34.6 \pm 2.8$ & $56.5 \pm 4.4$ & $1057 \pm 82$ & $857.8 \pm 78.3$ \\
3-methyl ether (5) & $>100$ & $>100$ & $>100$ & $>3000$ & $>3000$ \\
Ethyl $\beta$-D-glucoside (6) & $55.3 \pm 1.8$ & - & - & - & - \\
Ascorbic acid & - & $18.9 \pm 1.05$ & $32.1 \pm 2.5$ & - & - \\
(+)-Catechin & - & - & - & $1020 \pm 85$ & $623.9 \pm 60.2$ \\
Acarbose & - & & &
\end{tabular}

$* \mathrm{IC}_{50}$ values in $\mu \mathrm{M}$ are mean $\pm \mathrm{SD}$ from triplicate experiments.

\subsection{Chemotaxonomy}

In the present investigation, we isolated and identified six metabolites from the roots of $D$. difformis (Berberidaceae), including one aryltetralin lignan, three flavonols, a novel 2,3-dioxygenated flavanone, and an alkyl glycoside. Our findings highlight the need for further chemotaxonomic studies of the Dysosma genus and the Berberidaceae family. Podophyllotoxin (1) has previously been isolated from the Dysosma [3], Sinopodophyllum [24], Podophyllum [25], and Diphylleia [18] genera of the Berberidaceae family. However, this compound is not present in other well-known genera in the same family, such as Epimedium, Vancouveria, Mahonia, and Berberis. Thus, podophyllotoxin might be a valuable marker for distinguishing between plants within the Berberidaceae family. Moreover, we isolated podoverin A (3), 8,2'-diprenyl quercetin 3-methyl ether (5), and ethyl $\beta$-D-glucoside (6) from a Dysosma species for the first time. The discovery of these compounds has extended our phytochemical knowledge of the genus Dysosma. While podoverin A (3) is present Sinopodophyllum [26] and Podophyllum [19] species, 8,2'-diprenyl quercetin 3-methyl ether (5) has only been found in Sinopodophyllum [21]; this suggests a close relationship between the Dysosma and Sinopodophyllum genera. A previous phylogenetic study of Berberidaceae found that the Dysosma genus was more closely related to Sinopodophyllum than to Podophyllum, despite their similar morphology [27]. Therefore, compound $\mathbf{5}$ could be an important chemotaxonomic marker, enabling the identification of these genera.

Although compound $\mathbf{2}$ may be an artefact of ethanol extraction, the isolation of dysosmaflavanone (2) may instead have revealed the presence of 2,3-dioxygenated flavanone backbone in D. difformis. A variety of flavonoids have been isolated from several Berberidaceae genera [24, 28-33], to our knowledge, this is the report of isolation of a 2,3-dioxygenated flavanone from the family.

\section{Acknowledgments}

This work is supported by the National Foundation for Science and Technology Development (grant code: 106-NN.03-2016.49). 
New 2,3-dioxygenated flavanone from Dysosma difformis

\section{Supporting Information}

Supporting information accompanies this paper on http://www.acgpubs.org/journal/records-ofnatural-products

\section{ORCID}

Bui Van Thanh: 0000-0002-0128-1196

Nguyen Thi Van Anh: 0000-0001-7018-9441

Chu Thi Thu Ha: 0000-0002-3479-9469

Do Hoang Giang: 0000-0001-9227-6992

Truong Thi Lien: 0000-0003-0619-8583

Ninh Khac Thanh Tung: 0000-0003-3572-4845

Nguyen Tien Dat: 0000-0003-3645-5157

\section{References}

[1] C.V. Vo (2012). Dictionary of Vietnamese Medicinal Plants. Medicine Publisher, Hanoi, Vietnam.

[2] M.L. Yin, Z.L. Chen, Z.S. Gu and Y.X. Xie (1989). Dysoanthraquinone and 2demethyldysoanthraquinone from Dysosma majoense, Acta. Chim. Sin. 7, 468-470.

[3] P.Z. Yu, L.P. Wang and Z.N. Chen (1991). A new podophyllotoxin-type lignan from Dysosma versipellis var. tomentosa, J. Nat. Prod. 54, 1422-1424.

[4] Y. Zheng, Y.G. Xie, Y. Zhang, T. Li, H.L. Li, S.K. Yan, H.Z. Jin and W.D. Zhang (2016). New norlignans and flavonoids of Dysosma versipellis, Phytochem. Lett. 16, 75-81.

[5] Y. Zheng, J. Ye, Y.G. Xie, H.L. Li and H.Z. Jin (2017). Chemical constituents of Dysosma versipellis, Chem. Nat. Compd. 53, 151-153.

[6] X. Xu, X. Gao, L. Jin, P.S. Bhadury, K. Yuan, D. Hu, B. Song and S. Yang (2011). Antiproliferation and cell apoptosis-inducing bioactivities of constituents from Dysosma versipellis in PC3 and Bcap-37 cell lines, Cell. Div. 6, 14.

[7] H. Ardalani, A. Avan and M.G. Mobarhan (2017). Podophyllotoxin: a novel potential natural anticancer agent, Avicenna J. Phytomed. 7, 285-294.

[8] F. Liang, Y. Han, H. Gao, S. Xin, S. Chen, N. Wang, W. Qin, H. Zhong, S. Lin, X. Yao and S. Li (2015). Kaempferol identified by zebrafish assay and fine fractionations strategy from Dysosma versipellis inhibits angiogenesis through VEGF and FGF pathways, Sci. Rep. 5, 14468.

[9] R.W. Jiang, J.R. Zhou, P.M. Hon, S.L. Li, Y. Zhou, L.L. Li, W.C. Ye, H.X. Xu, P.C. Shaw and P.P.H. But (2007). Lignans from Dysosma versipellis with inhibitory effects on prostate cancer cell lines, $J$. Nat. Prod. 70, 283-286.

[10] J. Zhang, S.Y. Shi, M.J. Peng, J. Pan, H. Wan and C.S. Zhou (2014). Simultaneous determination of five active compounds from Dysosma difformis roots by HPLC, J. Liq. Chromatogr. Relat. Technol. 37, 1226-1236.

[11] N.T. Dung, M.T. Long, B.H. Cuong and P.T. Thuong (2018). Flavonoids and lignans from the underground parts of Podophyllum tonkinense Gagnep. collected in Sa Pa and Lao Cai, Viet. Pharm. J. 7, 158 .

[12] W.B. Williams, M.E. Cuvelier and C. Berset (1995). Use of a free radical method to evaluate antioxidant activity, Lebensm. Wiss. Technol. 28, 25-30.

[13] P.T. Thuong, N.D. Su, T.M. Ngoc, T.M. Hung, N.H. Dang, N.D. Thuan, K.H. Bae and W.K. Oh (2009). Antioxidant activity and principles of Vietnam bitter tea Ilex kudingcha, Food Chem. 113, 139145.

[14] T.T.H. Hanh, N.M. Chau, L.H. Tram, N.T. Luyen, P.T. Binh, C.V. Minh, N.H. Nam and N.T. Dat (2013). Inhibition of $\alpha$-glucosidase and $\alpha$-amylase from Cyperus rotundus, Pharm. Biol. 52, 74-77.

[15] N.H. Yoo, D.S. Jang, J.L. Yoo, Y.M. Lee, Y.S. Kim, J.H. Cho and J.S. Kim (2008). Erigeroflavanone, a flavanone derivative from the flowers of Erigeron annuus with protein glycation and aldose reductase inhibitory activity, J. Nat. Prod. 71, 713-715.

[16] N.K. Vu, C.S. Sub, M.T. Ha, Q.T. Ngo, S.E. Park, H. Kwon, D. Lee, J.S. Choi, J.A. Kim and B.S. Min (2020). Antioxidant and antidiabetic activities of flavonoid derivatives from the outer skins of Allium cepa L., J. Agric. Food Chem. 68, 8797-8811. 
[17] K.A. Mustafa, N.B. Perry and R.T. Weavers (2003). 2-Hydroxyflavanones from Leptospermum polygalifolium subsp. polygalifolium - Equilibrating sets of hemiacetal isomers, Phytochemistry 64, 1285-1293.

[18] A.J. Broomhead and P.M. Dewick (1990). Tumour-inhibitory aryltetralin lignans in Podophyllum versipelle, Diphylleia cymosa, and Diphylleia grayi, Phytochemistry 29, 3831-3837.

[19] H. Arens, B. Ulbrich, H. Fischer, M.J. Parnham and A. Römer (1986). Novel anti-inflammatory flavonoids from Podophyllum versipelle cell culture, Planta Med. 52, 468-473.

[20] F. Li, S. Guo, S. Zhang, S. Peng, W. Cao, C.T. Ho and N. Bai (2019). Bioactive constituents of $F$. esculentum bee pollen and quantitative analysis of samples collected from seven areas by HPLC, Molecules 24, 2705.

[21] Y. Kong, J.J. Xiao, S.C. Meng, X.M. Dong, Y.W. Ge, R.F. Wang, M.Y. Shang and S.Q. Cai (2010). A new cytotoxic flavonoid from the fruit of Sinopodophyllum hexandrum, Fitoterapia 81, 367-370.

[22] W. Li, K. Koike, Y. Asada, T. Yoshikawa and T. Nikaido (2003). Biotransformation of low-molecularweight alcohols by Coleus forskohlii hairy root cultures, Carbohydr. Res. 338, 729-731.

[23] C. Canel, R.M. Moraes, F.E. Dayan and D. Ferreira (2000). Podophyllotoxin, Phytochemistry 54, 115120.

[24] C. Zhao, J. Huang, A. Nagatsu and Y. Ogihara (2001). Two new podophyllotoxin glucosides from Sinopodophyllum emodi (Wall.) Ying, Chem. Pharm. Bull. 49, 773-775.

[25] D.E. Jackson and P.M. Dewick (1984). Aryltetralin lignans from Podophyllum hexandrum and Podophyllum peltatum, Phytochemistry 23, 1147-1152.

[26] Y.J. Sun, Z. Hao, J.G. Si, Y. Wang, Y.L. Zhang, J.M. Wang, M.L. Gao and H. Chen (2015). Prenylated flavonoids from the fruits of Sinopodophyllum emodi and their cytotoxic activities, RSC Advances $\mathbf{5}$, 82736-82742.

[27] Y.D. Kim, S.H. Kim, C.H. Kim and R.K. Jansen (2004). Phylogeny of Berberidaceae based on sequences of the chloroplast gene $n d h F$, Biochem. Syst. Ecol. 32, 291-301.

[28] M. Mizuno, M. Iinuma, T. Tanaka, N. Sakakibara, T. Fujikawa, S. Hanioka, Y. Ishida, X.S. Liu and H. Murata (1988). Flavonol glycosides in the roots of Epimedium diphyllum, Phytochemistry 27, 36453647.

[29] M. Mizuno, Y. Kanie, M. Iinuma, T. Tanaka and F.A. Lang (1991). Two flavonol glycosides, hexandrasides $\mathrm{C}$ and $\mathrm{D}$, from the underground parts of Vancouveria hexandra, Phytochemistry 30, 2765-2768.

[30] M. Mizuno, Y. Kanie, M. Iinuma, T. Tanaka and F.A. Lang (1992). Two flavonol glycosides from Vancouveria hexandra, Phytochemistry 31, 297-299.

[31] G.J. Wang, T.H. Tsai and L.C. Lin (2007). Prenylflavonol, acylated flavonol glycosides, and related compounds from Epimedium sagittatum, Phytochemistry 68, 2455-2464.

[32] X.D. Su, W. Li, J.Y. Ma and Y.H. Kim (2018). Chemical constituents from Epimedium koreanum Nakai and their chemotaxonomic significance, Nat. Prod. Res. 32, 1-5.

[33] Y. Sun, H. Chen, J. Wang, M. Gao, C. Zhao, R. Han, H. Chen, M. Li, G. Xue and W. Feng (2019). Sixteen new prenylated flavonoids from the fruit of Sinopodophyllum hexandrum, Molecules 24, 3196.

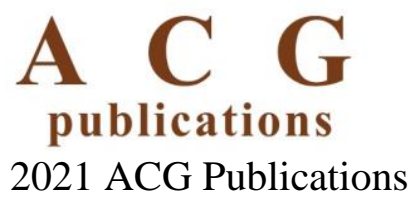

